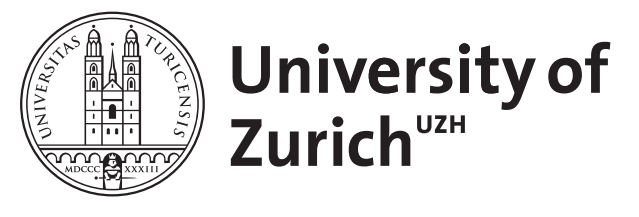

\title{
Swimming in ice cold water
}

\author{
Knechtle, B ; Christinger, N ; Kohler, G ; Knechtle, P ; Rosemann, T
}

\begin{abstract}
INTRODUCTION: We investigated two athletes swimming in 4 degrees C for 23 min (1.3 $\mathrm{km}$, swimmer 1) and $42 \mathrm{~min}(2.2 \mathrm{~km}$, swimmer 2), respectively. MATERIALS AND METHODS: Pre swim, percent body fat was determined; post swim, core temperature was measured. RESULTS: The core temperature of swimmer 2 was: 37.0 degrees $\mathrm{C}$ immediately before the start, 32 degrees $\mathrm{C} 20$ min after getting out of the water, and 35.5 degrees C 80 min after finishing the swim. CONCLUSION: We assume that the higher skin-fold thickness and body fat of swimmer 2 enabled him to perform longer. In addition to this, mental power and experience in cold water swimming must be considered. In any athlete aiming at swimming in water of less than 5 degrees $\mathrm{C}$, body core temperature and heart rate should be continuously monitored in order to detect a body core temperature below 32 degrees $\mathrm{C}$ and arrhythmia to pull the athlete out of the water before life-threatening circumstances occur.
\end{abstract}

DOI: https://doi.org/10.1007/s11845-009-0427-0

Posted at the Zurich Open Repository and Archive, University of Zurich

ZORA URL: https://doi.org/10.5167/uzh-27701

Journal Article

Published Version

Originally published at:

Knechtle, B; Christinger, N; Kohler, G; Knechtle, P; Rosemann, T (2009). Swimming in ice cold water. Irish Journal of Medical Science, 178(4):507-511.

DOI: https://doi.org/10.1007/s11845-009-0427-0 


\title{
Swimming in ice cold water
}

\author{
B. Knechtle $\cdot$ N. Christinger $\cdot$ G. Kohler $\cdot$ \\ P. Knechtle $\cdot$ T. Rosemann
}

Received: 3 May 2009/Accepted: 16 August 2009/Published online: 11 September 2009

(C) Royal Academy of Medicine in Ireland 2009

\begin{abstract}
Introduction We investigated two athletes swimming in $4^{\circ} \mathrm{C}$ for $23 \min (1.3 \mathrm{~km}$, swimmer 1$)$ and $42 \min (2.2 \mathrm{~km}$, swimmer 2), respectively.

Materials and methods Pre swim, percent body fat was determined; post swim, core temperature was measured.

Results The core temperature of swimmer 2 was: $37.0^{\circ} \mathrm{C}$ immediately before the start, $32^{\circ} \mathrm{C} 20 \mathrm{~min}$ after getting out of the water, and $35.5^{\circ} \mathrm{C} 80 \mathrm{~min}$ after finishing the swim. Conclusion We assume that the higher skin-fold thickness and body fat of swimmer 2 enabled him to perform longer. In addition to this, mental power and experience in cold water swimming must be considered. In any athlete aiming at swimming in water of less than $5^{\circ} \mathrm{C}$, body core temperature and heart rate should be continuously monitored in order to detect a body core temperature below $32^{\circ} \mathrm{C}$ and arrhythmia to pull the athlete out of the water before life-threatening circumstances occur.
\end{abstract}

Keywords Hypothermia $\cdot$ Rectal temperature

Body fat $\cdot$ Skin-fold thickness

B. Knechtle $(\bowtie) \cdot$ N. Christinger $\cdot$ P. Knechtle

Gesundheitszentrum St. Gallen, Vadianstrasse 26,

9001 St. Gallen, Switzerland

e-mail: beat.knechtle@hispeed.ch

B. Knechtle · T. Rosemann

Institute of General Practice and for Health Services Research,

University of Zurich, Zurich, Switzerland

G. Kohler

Radio-oncology, University Hospital, Basel, Switzerland

\section{Introduction}

Endurance swimming in cold water is limited due to hypothermia. When body core temperature drops below $32^{\circ} \mathrm{C}$, there is a progressive risk of spontaneous ventricular fibrillation and death [1].

There are a few reports in the literature about swimmers in cold water. Acevedo et al. [2] described, in a case study, a swimmer preparing in $18^{\circ} \mathrm{C}$ for the English Channel. Nuckton et al. [3] reported about 11 subjects swimming in $11.7^{\circ} \mathrm{C}$. Keatinge et al. [1] characterised eight cold water swimmers in $9.4-11^{\circ} \mathrm{C}$ and Tipton et al. [4] reported on five athletes swimming at $10^{\circ} \mathrm{C}$.

Swimming in water of less than $10^{\circ} \mathrm{C}$ has not been reported. People immersed after shipwreck in water colder than $6^{\circ} \mathrm{C}$ usually die of hypothermia within $75 \mathrm{~min}$ [5]. However, it is possible to survive in water of $5-6^{\circ} \mathrm{C}$ when drifting in clothes for 5-6 h [6].

As far as we are aware, up to now no report of elite swimmers in ice cold water at $4^{\circ} \mathrm{C}$ has been published. We report here about two elite swimmers performing in $4^{\circ} \mathrm{C}$.

\section{Methods}

Subjects and their preparation for the swim

The anthropometry of the two swimmers, both originating from Cape Town, South Africa, is represented in Table 1. The physical training of both swimmers was swimming for 5-6 days of the week for $1 \mathrm{~h}$ covering approximately $2.5 \mathrm{~km}$ per session. In the preparation for the event, both swimmers regularly performed sea swims in water of $18^{\circ} \mathrm{C}$ for $40 \mathrm{~min}$ over $1.6 \mathrm{~km}$. Furthermore, swimmer $1 \mathrm{com}$ pleted ice baths for $3 \mathrm{~min}$ at $1.5^{\circ} \mathrm{C}$ and then another $3 \mathrm{~min}$ 
at $2.5^{\circ} \mathrm{C}$. Swimmer 2 spent $3 \mathrm{~min}$ at $0.4^{\circ} \mathrm{C}$ and $7 \mathrm{~min}$ at $3^{\circ} \mathrm{C}$ while swimmer 1 spent $10 \mathrm{~min}$ at $3^{\circ} \mathrm{C}$. Twelve days before the planned event, they both swam $45 \mathrm{~min}$ in the sea at $10.5^{\circ} \mathrm{C}$; 9 days before, they did $7.5 \mathrm{~km}$ in $2 \mathrm{~h} 29 \mathrm{~min}$ at $11.5^{\circ} \mathrm{C}$. Swimmer 2 swam $1 \mathrm{~km}$ in $1^{\circ} \mathrm{C}$ in Antarctica in February 2008, in a time of $22 \mathrm{~min}$. No medical information is available for the swim but it was supervised by experienced polar explorers and a doctor. Both athletes also prepared mentally for the ice swim. Swimmer 1 was reading literature about extreme cold and problems in a cold environment. Swimmer 2 watched movies of ice swimming and ice diving. This gave him a good idea of what these people did and how they reacted. Furthermore, he ran the swim many times in his mind, going over the phase before the swim, the entry into the water, the first few minutes to settle the breathing, dealing with the initial pain and then getting into a rhythm. Two days before the swim, in Lake Zurich, they swam for $10 \mathrm{~min}$ on the planned course. They walked on the Lake shore to determine the exact route of the swim and to prepare mentally for the course.

Pre-event measurements and calculations

The day before the swim, red blood cells, white blood cells, platelets, haemoglobin, haematocrit, mean corpuscular volume (MCV), mean corpuscular haemoglobin $(\mathrm{MCH})$ and mean corpuscular haemoglobin concentration (MCHC) were measured using ABX Micros CRP 200 (Horiba ABX Diagnostics, Northampton, UK). Liver enzymes (GOT and GPT) and creatine kinase (CK) were determined using

Table 1 Anthropometric measurements of the swimmers before the event

\begin{tabular}{lcc}
\hline & Swimmer 1 & Swimmer 2 \\
\hline Body mass (kg) & 86.5 & 75.1 \\
Body height (m) & 1.79 & 1.79 \\
BMI (kg/m ${ }^{2}$ ) & 27.0 & 23.4 \\
Skin-fold chest (mm) & 5.6 & 15.4 \\
Skin-fold midaxillary (mm) & 14.6 & 12.6 \\
Skin-fold triceps (mm) & 7.4 & 10.0 \\
Skin-fold subscapular (mm) & 14.6 & 15.8 \\
Skin-fold abdominal (mm) & 29.8 & 29.0 \\
Skin-fold suprailiac (mm) & 35.2 & 33.4 \\
Skin-fold thigh (mm) & 11.0 & 15.0 \\
Skin-fold calf (mm) & 6.6 & 8.6 \\
Sum of eight skin-folds (mm) & 124.8 & 139.8 \\
Mean skin-fold thickness (mm) & 15.6 & 17.4 \\
Body fat (\%) & 21.0 & 23.4 \\
Calculated fat mass (kg) & 18.2 & 17.6 \\
Calculated skeletal muscle mass (kg) & 43.1 & 35.1 \\
\hline
\end{tabular}

Spotchem $^{\text {TM }}$ EZ SP-4430 (ARKRAY, Amstelveen, The Netherlands). Lung function with functional vital capacity (FVC) and forced expiratory volume $\left(\mathrm{FEV}_{1}\right)$ was determined using Easy one ${ }^{\mathrm{TM}}$ diagnostic Spirometer (Ingelheim am Rhein, Germany). Resting electrocardiogram (ECG) was recorded using CARDIOVIT AT-102 (Schiller, Linz, Austria). Blood pressure was measured using a sphygmomanometer to the nearest $5 \mathrm{~mm} \mathrm{Hg}$. Body core temperature was measured rectally using an alcohol-mercury thermometer $\left(-10\right.$ to $+50^{\circ} \mathrm{C}$, scaled to $\left.0.5^{\circ} \mathrm{C}\right)$ to the nearest $0.5^{\circ} \mathrm{C}$. Body mass, body fat percentage [7] and skeletal muscle mass [8] were determined using the anthropometric method. Body fat percentage was calculated using the formula according to Ball et al. [7]. Skeletal muscle mass was calculated using the formula according to Lee et al. [8]. Skin-fold thicknesses of chest, midaxillary (vertical), triceps, subscapular, abdominal (vertical), suprailiac (at anterior axillary), thigh and calf were measured using a skin-fold calliper (GPM-Hautfaltenmessgerät, Siber \& Hegner, Zurich, Switzerland) to the nearest $0.2 \mathrm{~mm}$ on the right side of the body. One trained investigator took all the measurements, as inter-tester variability is a major source of error in skin-fold measurements. Circumferences of the upper arm, thigh and calf were measured at the largest circumference of the limb to the nearest $0.1 \mathrm{~cm}$. At the thigh, circumference was determined $20 \mathrm{~cm}$ above the upper pole of the patella.

Immediately before the start of the swim, blood pressure, heart rate and rectal temperature were measured. During the swim, heart rate was continuously measured using a portable heart rate monitor POLAR S710 (Polar Electro Oy, Kempele, Finland). The support crew had direct visual contact with the swimmers and recorded the stroke rate every minute.

The event

The swim was held on 30 January 2009 in Lake Zurich (406 $\mathrm{m}$ above sea level) and started at 02:00 p.m. The actual local weather conditions at the start time were provided by the Sea Police Zurich. At the start of the swim the water temperature was $4.3^{\circ} \mathrm{C}$, the air temperature was $0.8^{\circ} \mathrm{C}$, and humidity was $76 \%$. The wind direction was from the north-east $\left(48^{\circ}\right)$ blowing at $4 \mathrm{~m} / \mathrm{s}$ with a wind chill of $-7.5^{\circ} \mathrm{C}$ and barometric pressure was at $971 \mathrm{hPa}$. The start of the swim was at 'Casino Zürichhorn' and the athletes swam close to the shore in a northerly direction to 'Bellevue' in the city of Zurich. About $50 \mathrm{~m}$ before the finish, the swimmers had to swim under a bridge and then turn to the right to climb up steps to get out of the water. Each swimmer was followed by a police boat with resuscitation equipment, a diver and medical personal in case of emergency. A swimmer could stop voluntarily, give a hand signal and would then be rescued by his own lifeboat. In 
case the stroke rate dropped below 30 beats per minute and the swim style became uncoordinated, the diver would jump into the water and pull the swimmer out of the lake before he lost consciousness. There was no telemetric system to monitor heart rate or body core temperature. The swimmers were wearing a standard Speedo swim suit, a pair of goggles and a standard silicon cap. No greasing was done. No ear plugs or other methods of reducing exposure to cold were used.

\section{Results}

Table 1 summarises the anthropometric measurements, and Table 2 shows the laboratory data measured the day before the swim. The ECG of both swimmers showed no abnormalities. Immediately before the start, the blood pressure of swimmer 1 was 180/100 mm Hg and swimmer 2 was 140/ $90 \mathrm{~mm} \mathrm{Hg}$. Body core temperature was at $37.2^{\circ} \mathrm{C}$ in swimmer 1 and $37.0^{\circ} \mathrm{C}$ in swimmer 2 .

The swimmers started together, swimming side by side and looking at each other. Figure 1 shows the stroke and heart rate during the swim. Swimmer 1 stopped after 23 min having covered $1.3 \mathrm{~km}$. During the swim, he repeated the names of his family members. When he realised that he was not able to continuously repeat the names, he slowed down, lost contact with swimmer 2 and stopped the swim of his own volition. He swam towards the support boat and was pulled out of the water. On the boat, he was conscious. The support crew wrapped him in blankets and transferred him onto shore and back to the

Table 2 Laboratory data before the event

\begin{tabular}{|c|c|c|}
\hline & Swimmer 1 & Swimmer 2 \\
\hline White blood cells $\left(10^{3} / \mathrm{mm}^{3}\right)$ & 7.5 & 8.3 \\
\hline Red blood cells $\left(10^{6} / \mathrm{mm}^{3}\right)$ & 5.0 & 5.7 \\
\hline Platelets $\left(10^{3} / \mathrm{mm}^{3}\right)$ & 232 & 247 \\
\hline Haemoglobin (g/dl) & 14.0 & 16.4 \\
\hline Haematocrit & 42.8 & 50.7 \\
\hline $\operatorname{MCV}\left(\mu \mathrm{m}^{3}\right)$ & 85.5 & 88.1 \\
\hline $\mathrm{MCH}(\mathrm{pg})$ & 28.0 & 28.4 \\
\hline $\mathrm{MCHC}(\mathrm{g} / \mathrm{dl})$ & 32.7 & 32.3 \\
\hline GOT (U/l) & 19 & 13 \\
\hline GPT (U/l) & 23 & 14 \\
\hline Creatinine (U/1) & 107 & 52 \\
\hline FVC (1) & 5.38 & 4.53 \\
\hline $\mathrm{FEV}_{1}(\mathrm{l})$ & 4.61 & 3.13 \\
\hline $\mathrm{FEV}_{1} / \mathrm{FVC}$ & 0.86 & 0.69 \\
\hline Blood pressure $(\mathrm{mm} \mathrm{Hg})$ & $115 / 70$ & $140 / 75$ \\
\hline Heart rate (bpm) & 61 & 55 \\
\hline
\end{tabular}

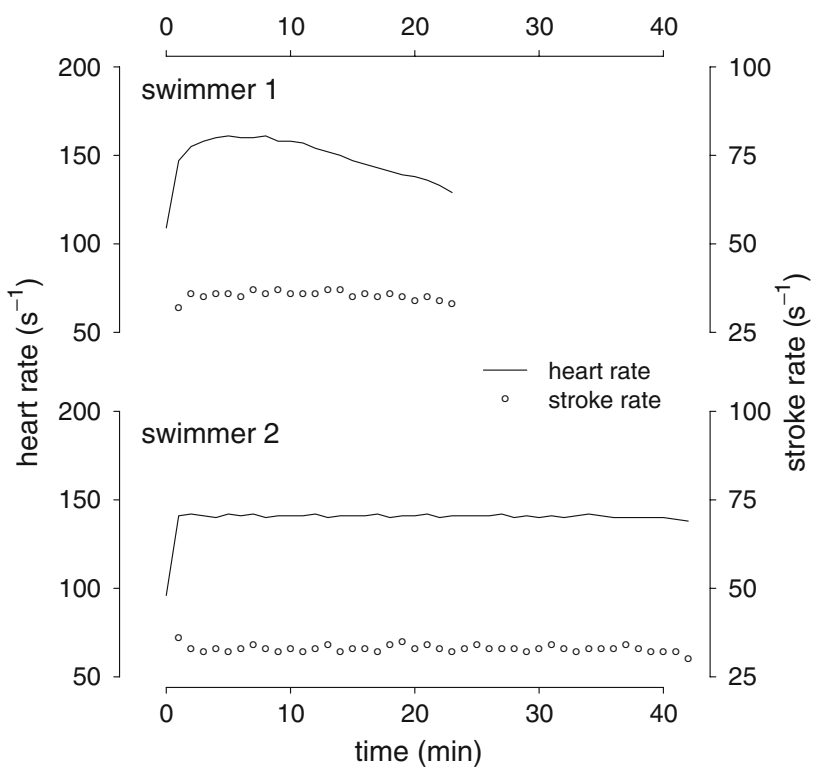

Fig. 1 Time course of heart rate and stroke rate in both swimmers

start where he could enter a heated building and take a hot shower. After full recovery, he complained about numbness in the fourth finger of the right hand. He reported that he had started faster than planned and developed tachy- and dyspnoea. After losing contact with swimmer 2, he swallowed lake water and was unable to continue the swim.

Swimmer 2 finished the $2.2 \mathrm{~km}$ after 42 min without external help. When he arrived at the finish, a diver helped him to get out of the water; he was not able to stand without help. He was conscious, but disorientated and practically unable to talk. He started shivering and was covered with blankets and immediately transferred into a heated car which took him to a heated indoor pool. During the 10-min drive, he started hyperventilating. He started to talk but was still disorientated. About $20 \mathrm{~min}$ after stopping the swim his body core temperature was at $32^{\circ} \mathrm{C}$ and he entered the heated pool $\left(31^{\circ} \mathrm{C}\right)$. He complained about increasing dizziness, but then walked with help to the showers where he took a hot shower for about $15 \mathrm{~min}$. After the shower he was able to stand without help and started dressing. Eighty minutes after finishing the swim his body core temperature was at $35.5^{\circ} \mathrm{C}$. About $3 \mathrm{~h}$ after getting out of the lake, the swimmer was completely recovered without any physical or mental after-effects. After full recovery, he reported that he had had increasing difficulties in breathing during the swim and that his hands got increasingly stiff. During the swim he counted from 0 to 100 in order to keep control. He realised in the last minutes - the finish before his eyes - that he was no longer able to count numbers and did not remember how he finished the swim and got out of the water. He did not even realise that a diver had helped him out of the water. A 
major problem during the swim was a stiff neck due to the wind chill.

\section{Discussion}

The most important problem of swimming in cold water is hypothermia [3]. The upper limit of hypothermia is accepted as $35^{\circ} \mathrm{C}$ [1] to $36^{\circ} \mathrm{C}$ [3]. Swimmer $2 \mathrm{had}, 20 \mathrm{~min}$ after the swim, a core temperature of $32^{\circ} \mathrm{C}$. This was after a drive in a heated car with the athlete wrapped in blankets. We must assume that his core temperature immediately after the swim was lower than $32^{\circ} \mathrm{C}$ where a progressive risk of spontaneous ventricular fibrillation and death exists [1]. However, we must be aware of the 'afterdrop phenomenon' as described by Nuckton et al. [3]. Ten out of their 11 subjects swimming in $11.7^{\circ} \mathrm{C}$ experienced afterdrop defined as continued cooling after removal from cold stress. Presumably, regarding this phenomenon, body core temperature in swimmer 2 was rather higher immediately after the swim.

The drop in body core temperature during swimming in cold water can lead to ventricular fibrillation and death [1]. Telemetry with constant observation of ECG would be desirable to detect arrhythmia. In this actual setting, the only possibility of having control over the swimmers was direct visual contact and observation from the support boat, and calculating the stroke rate. Both swimmers were relatively constant with their stroke rate (Fig. 1). Tipton et al. [4] concluded with their swimmers, at 25,18 and $10^{\circ} \mathrm{C}$, that swimming efficacy and length of stroke seem to characterise swim failure in cold water. We saw that swimmer 2 became unable to concentrate in the last 2 min of the swim and this was also represented by the lower stroke rate. However, we assume that this was not due to impairment of the central nervous function. We rather think that the swimmer was irritated by the dark under the bridge and the change of the support boats when he had to change direction. According to O'Brien et al. [9], cognitive performance should be maintained at a core temperature of $35.5^{\circ} \mathrm{C}$.

It is assumed that swimmers with more body fat can perform longer in cold water [1] and an increase in fat mass is recommended [2] before a swim in cold water. In the study of Keatinge et al. [1], the subject with the thinnest skin-fold thickness (mean skin-fold thickness of 4 skinfolds) of $8.56 \mathrm{~mm}$ swam for $23 \mathrm{~min}$ in $11^{\circ} \mathrm{C}$. The subject with the highest skin-fold thickness $(21.5 \mathrm{~mm})$ swam for $65 \mathrm{~min}$ in $10^{\circ} \mathrm{C}$. Swimmer 2 performed twice as long as swimmer 1. The skin-folds of our swimmers might agree with the findings of Keatinge et al. [1]. Keatinge et al. [6] could show in an experimental setting that a large man of $1.93 \mathrm{~m}, 125 \mathrm{~kg}$ weight and an overall mean subcutaneous fat thickness of $14 \mathrm{~mm}$ could stay for $83 \mathrm{~min}$ in $5.3^{\circ} \mathrm{C}$, and the rectal temperature fell by only $1.15^{\circ} \mathrm{C}$. It is obviously possible that body core temperature can also be stabilised in cold water of about $5^{\circ} \mathrm{C}$, presumably due to fat thickness.

In a recent study [10], a higher BMI was associated with a decreased risk of hypothermia. However, we had different findings in our athletes. Swimmer 1 had a lower sum of total skin-fold thickness, a lower mean skin-fold thickness and a lower percent body fat. Although BMI of swimmer 1 was higher compared to swimmer 2 , he had to give up earlier. Swimmer 1 had a higher muscle mass compared to swimmer 2, the higher muscle mass was responsible for the higher BMI (Table 1) although calculated fat mass was higher in swimmer 1 compared to swimmer 2 .

A further important aspect to swimming in ice cold water is mental power. Swimmer 2 was experienced in swimming in ice cold water since he had already swam in Antarctica. After his 22-min swim in Antarctica we wanted to improve his performance and enable him to swim longer. Swimmer $1 \mathrm{knew}$ that up to now a limit of about 22 min had been set in ice cold water by swimmer 2 , and probably stopped at this point because of a mental barrier.

\section{Conclusions}

A male athlete could swim for $42 \mathrm{~min}$ in $4{ }^{\circ} \mathrm{C}$ and reach a distance of $2.2 \mathrm{~km}$. The thickness of skin-folds was presumably an important factor, not BMI. His final core temperature of $32^{\circ} \mathrm{C}$ was very close to the risk of spontaneous ventricular fibrillation and death. In any future athlete aiming at swimming in ice cold water for longer than 42 min body core temperature and heart rate should be monitored by radiotelemetry in order to detect a decrease in body core temperature below $32^{\circ} \mathrm{C}$ and cardiac arrhythmia in order to pull the athlete out of the water before life-threatening circumstances occur.

Acknowledgments We thank Marco Pilloud, Total Immersion Europe, Zurich, Switzerland, for organising the event and Amanda Picard for her assistance with swimmers and organisation. Sincere thanks goes to the Sea Police Zurich for providing exact weather data and rescue boats during the swim. Matthias Knechtle, Lausanne, Switzerland, and Mary Miller, England, helped us with the translation.

\section{References}

1. Keatinge WR, Khartchenko M, Lando N, Lioutov V (2001) Hypothermia during sports swimming in water below $11^{\circ} \mathrm{C}$. Br J Sports Med 35:352-353

2. Acevedo EO, Meyers MC, Hayman M, Haskin J (1997) Applying physiological principles and assessment techniques to swimming 
the English Channel. A case study. J Sports Med Phys Fitness 37:78-85

3. Nuckton TJ, Claman DM, Goldreich D, Wendt FC, Nuckton JG (2000) Hypothermia and afterdrop following open water swimming: the Alcatraz/San Fransisco Swim Study. Am J Emerg Med 18:703-707

4. Tipton M, Eglin C, Gennser M, Golden F (1999) Immersion deaths and deterioration in swimming performance in cold water. Lancet 354:626-629

5. Molnar GW (1946) Survival of hypothermia by men immersed in the ocean. JAMA 131:1046-1050

6. Keatinge WR, Coleshaw SR, Millard CE, Axelsson J (1986) Exceptional case of survival in cold water. Br Med J (Clin Res Ed) 292:171-172
7. Ball SD, Altena TS, Swan PD (2004) Comparison of anthropometry to DXA: a new prediction equation for men. Eur J Clin Nutr 58:1525-1531

8. Lee RC, Wang Z, Heo M, Ross R, Janssen I, Heymsfield SB (2000) Total-body skeletal muscle mass: development and crossvalidation of anthropometric prediction models. Am J Clin Nutr 72:796-803

9. O'Brien C, Tharion WJ, Sils IV, Castellani JW (2007) Cognitive, psychomotor, and physical performance in cold air after cooling by exercise in cold water. Aviat Space Environ Med 78:568-573

10. Brannigan D, Rogers IR, Jacobs I, Montgomery A, Williams A, Khangure N (2009) Hypothermia is a significant medical risk of mass participation long-distance open water swimming. Wilderness Environ Med 20:14-18 